\title{
DESTINY, MIRACLE HEALERS AND MAGICAL INTERVENTION: VERNACULAR BELIEFS ON INVOLUNTARY CHILDLESSNESS IN ESTONIA
}

\author{
REET HIIEM ÄE \\ $\mathrm{PhD}$, Researcher \\ Department of Folkloristics, Estonian Literary Museum \\ Vanemuise 42, 51003 Tartu, Estonia \\ e-mail: reet@folklore.ee
}

\begin{abstract}
The article ${ }^{*}$ focuses on the dynamics of contemporary beliefs related to involuntary childlessness. Firstly, the methodological issues of collecting source material on delicate matters and the advantages of anonymous and narrative presentation modes in certain contexts will be discussed. Secondly, conclusions drawn from the collected material, i.e. the temporary and changeable nature of those beliefs, their relations with the mass media, the social and the individual aspects and the motifs of guilt and supernatural punishment in the context of identity issues will be presented, concluding that such belief-based models of explanation and help-seeking eventually function as a mental self-defence mechanism.
\end{abstract}

KEYWORDS: infertility $\bullet$ vernacular beliefs $\bullet$ the dynamics of beliefs $\bullet$ magic

\section{INTRODUCTION}

Involuntary childlessness occurs globally and references to it being seen as a problem can be found in sources thousands of years old. However, the beliefs and stereotypes related to infertility - the attitudes towards childless people, the causes of infertility and the treatment of infertility - differ by culture, depending on the belief background and religious traditions of each society. The culturally acceptable types of reproduction also depend on vernacular beliefs and worldview (for example the concepts of soul or god) (cf. Knecht 2010: 9; Franklin 2013). At the same time, the attitudes related to childlessness can shift a lot in just a couple of decades even within one culture (cf. Roberts 2012: xxiii).

Among researchers, infertility has been viewed primarily as a medical problem in Estonia. The issues faced by childless people coping with the role, and the belief systems and cultural interpretation models they use to adapt to this temporary or per-

* The article was supported by institutional research grants IUT22-5 and IUT2-43 from the Estonian Ministry of Education and Research and by the European Union through the European Regional Development Fund (Centre of Excellence in Estonian Studies). 
manent role have been largely overlooked. Nonetheless, subjective worldviews have played a crucial role in the well-being and identity-building of many childless couples.

\section{THE AIM OF THIS STUDY}

This study focuses on vernacular beliefs about involuntary childlessness. I argue that various supernatural explanations and belief-based behavioural models act as coping mechanisms that, combined with medical solution-seeking, enables involuntarily childless people to make sense of their experience and gain a subjective feeling of control and hope. I also argue that such narratives and reactions have often a temporary character. To get an overview of such beliefs, I conducted an anonymous web survey that generated over 100 responses. The responses showed that although involuntary childlessness is generally perceived as a heavy psychological and social burden, the individuals going through it do not behave as passive victims but have developed various belief-based ways of coping (for example personal stories of contact with unborn children or angels, beliefs in supernatural causes of the situation that help to cope with childlessness, magical interventions). Thus, one of the main goals of this study is to see how vernacular beliefs function as a psychological self-defence strategy. The second and more general aim of this paper is to give the belief systems related to childlessness a more human face. On the one hand, the responses of the survey can be seen as a cultural document typical to the time period; analysing the responses, on the other hand, can help outsiders understand what childless people are going through. Hopefully, the study can also provide fertility doctors with some new insight on the matter. Patients' personal beliefs and rituals are usually not discussed during the consultations and their effect on patients' ability to cope with the problem or manage the related fears might remain unknown to doctors. At the same time 82 per cent of the responses indicated that either the respondent or somebody they knew had magical beliefs related to childlessness.

\section{THEORETICAL B A SELINE}

There are only few specific studies on magical beliefs related to involuntary childlessness (for example Bernstein et al. 1992), it is therefore appropriate to first define the terms 'magic' and 'behaviour triggered by magical beliefs' in this context, as the following analysis revolves around those aspects. In more general studies, some folklorists and anthropologists have used the concept of magic as an analytical perspective to better understand and conceptualise the mental models and behaviours that - depending on situation, context and observer - can first seem unreasonable or incomprehensible (cf. Tjørnhøj-Thomsen and Hansen 2015: 95). The majority of such scholars agree that magical beliefs can be characterised by the presupposition of the existence of certain supernatural powers or causalities not yet scientifically proven but held possible by the users of such beliefs, also understanding the users to presume that with the help of certain manipulations such powers can be engaged for their own benefit (cf. Brückner 1970: 786; Petzoldt 2011: 20). Apart from childlessness, magical thinking can be seen 
today accompanying a number of different medical conditions and other life situations involving insecurity and danger (cf. for instance Lloreda-Garcia 2017 about magic and spirituality in neonatal units). In the context of this study, magical beliefs and beliefdriven behaviour are understood as repeated mental models and directing activities with a ritual nature, that demonstrate certain parallels with traditional magic principles.

At the same time, in most cases today it is inapplicable to talk about a homogeneous magic worldview. It is characteristic to many magical approaches that they are used for a limited time only. When life gets back to normal or the users become disappointed in magic or gain new understandings, they can distance themselves from the approach. Additionally, people can take some of such approaches seriously or reject them, depending on context. Therefore, I will not attempt to oppose magical belief to science or science-based conventional medicine as both approaches can occur in combination or a person can switch from one to the other. Furthermore, in the context of beliefs connected with childlessness a paradox applies whereby supernatural ideation can actually arise for very rational and pragmatic reasons. The general theoretical background of this research is also based on the folkloristic and anthropological studies of narrative medicine (for example Tjørnhøj-Thomsen 2005; Paal 2010; Briggs 2012; Briggs and Briggs-Mantini 2016), medical anthropology and self-psychology (for example Leventhal et al. 1984; Moulet 2005). General information on the attitudes related to medical infertility treatment from the ethnological/anthropological point of view was obtained from the work of Michi Knecht (2010; Knecht et al. 2011), Sarah Franklin (2006a; 2006b) and Elizabeth Roberts (2012; 2016), the reflections of medics on the magical beliefs of childless patients can be found in the research of Joel Bernstein and his colleagues (Bernstein et al. 1992).

\section{METHODOLOGY}

A number of medical studies on the subjective perception of childlessness view infertility as a medical experience (see respective critical overview in Greil 1997), asking the patients of fertility clinics if they considered their condition temporary or permanent, if they considered a cure possible or not, etc. Psychological analyses mainly focus on the patients' cognition of self-esteem and psychological well-being (see for example Menning 1984; Malik and Coulson 2008). Anthropologists have written about societal values relating to infertility and reproductive technology, describing the interaction of the development of medical science with cultural understandings of family and parenthood (for example Rapp 2000; Thompson 2005; Franklin 2006a; Roberts 2012: 4-6). These studies constitute a broader context to the current article. However, the main emphasis of this study is on religious and belief-driven explanation models and magical interventions of childless people from a folkloristic perspective as only few previous studies touch upon these topics. Infertility and some other medical conditions have been analysed somewhat more from aspects of Christian religiosity (for example von Garmissen 2009 on the religious reasoning of breast cancer patients; Franklin 2006b). I agree with Roberts (2016: 209), who has recently called for a non-secular anthropology, pointing out that when deities are part of medical practice, they should also be integral to analysis. Magical beliefs have a significant impact on the mental processing of 
the experience of childlessness and related psychological well-being - as becomes clear from the responses to this survey.

Additionally, thus far the majority of studies regarding infertility are based on the statistical approach and conclusions are drawn from quantitative information (yes/no answers or numeric responses) (for example Malik and Coulson 2008; Nelson et al. 2008). One of the few exceptions is professor of medicine Helen Therese Allan's 2009 study that quotes longer descriptions from infertility patients on their individual perceptions. The quantitative approach fails to give a representative picture of the experience of childlessness because it does not reveal the symbolic or cultural background of the beliefs and does not enable people to understand the step-by-step embracing process and inner logic of the conclusions that are irrational from a scientific viewpoint. Thus, I saw a need for a women-centred folkloristic approach. I used open-ended questions in my survey because these enabled the respondents to write narrative responses, write as long as they pleased and focus on topics relevant to them. The narrative approach enabled the respondents to express their feelings, perceptions and beliefs in a more detailed, authentic and flexible way and made the unique voice of every respondent audible. It also helped to demonstrate the temporary nature of those beliefs - something that cannot be seen in statistical presentations. Thus, the folkloristic viewpoint of the study (such as, for example, in Paal 2010) provides an additional dimension to the topic of infertility.

One reason why magical beliefs connected with childlessness have not been studied enough is the unavailability of material. Survey responses confirmed my presumption that people often do not have the courage to talk about magic, rituals or supernatural beliefs because these do not seem to fit the generally accepted rational worldview. Other authors (for example Moulet 2005: 69, 71) have also pointed to difficulties finding people who would share their experience of childlessness in a face-to-face interview. It has also been observed that in those interviews, respondents tend to adjust their responses to the common societal norms or keep quiet about aspects they consider inappropriate. For this reason I conducted an anonymous online survey (the respondents were only asked to give their gender and age group). I wanted to distinguish between the age groups to see if beliefs changed with age, but no significant differences were detected. Respondents from all age groups were represented almost equally (only in the youngest age group (up to 25 years) were there fewer respondents for obvious reasons (9 respondents)). I worked with 100 completed questionnaires (later still more forms were completed but the general outcomes did not change). As expected, the majority of respondents were women: there were 90 female and 10 male respondents.

The topics presented in the survey related to general attitudes in society (for example regarding involuntary or voluntary childlessness, the role of a woman as mother, in vitro fertilisation; perceived societal accusations and the feelings of guilt of childless women). The respondents were also asked about their individual beliefs regarding the causes (God's will or punishment, karma, destiny, harmful magic, etc.) and treatments of infertility (protective and healing magic, charms, healing plants, special diets, visits to healers) and narratives about the same topics that they had heard from others. Recent statistical surveys about magical/religious beliefs in Estonia in general, as well as recurrent motifs that I encountered in family planning Internet forums, served as a backdrop for the choice of survey topics. ${ }^{1}$ 
My survey was distributed with the help of fertility doctors who told their patients about the possibility of participating in an online survey. A call for participation was also published in the Internet family forum Perekool (www.perekool.ee) since only a limited segment of childless people visit clinics. Several researchers (for example Moulet 2005: 243) had pointed out that infertility studies tend to focus only on the people who attend infertility clinics, leaving out those who do not undergo treatment or who have given it up. Some respondents were also found through personal contacts. Most responses arrived from February to June 2015, later additional responses continued to arrive in a smaller volume until May 2016.

The responses passed a qualitative analysis, in the course of which repeated belief elements were highlighted and grouped according to thematic fields and motifs (for example motifs related to karma, God's punishment, the evil eye, contacts with healers, protective magic). The same keywords were used to find additional material from the media and internet forums, combined with the frontal reading of all topics connected with childlessness in internet family and women's forums. I will, as follows, cite the responses by gender, response number and age group of the respondents, for example reference 'M20, age group 36-40' means a male respondent who belongs to the age group of 36-40 years; the designation $\mathrm{F}$ in front of the number of the response form refers to a female respondent, the designation $\mathrm{KOM}$ indicates that the passage was taken from an internet forum comment.

\section{ATTITUDES ON CHILDLESSNESS AND FERTILITY TREATMENT IN SOCIETY}

Since 1978 when the first 'test tube baby' was born, medical in vitro fertilisation has become a separate field of science and medicine (Throsby 2004: 1). The social positioning of medical infertility treatment from a sensational practice to a standard procedure has happened within a few decades. Some German ethnologists note that after the first baby was born with the help of artificial fertilisation in Germany, metaphors like "creating Frankensteins" or "sacrilegious frozen babies" could be heard in public discussions and there was a tendency to mix up reproductive medicine with cloning (Knecht et al. 2011: 29-30, more on these debates see Franklin 1999). In today's Estonia such grotesque statements are rare and within the past dozen years public attitude has become more tolerant towards fertility treatment and childlessness (most respondents said it). However, significant discrepancies were observed between the views of the persons affected by childlessness and the outsiders. Similar observations have been made elsewhere the results of a public survey conducted in Europe, USA and Australia demonstrated that individuals who had no personal connection with the issue of childlessness did not have adequate knowledge of the related medical causes or the percentage of successful medical interventions (Adashi et al. 2000: 333). Although numerous scientific articles have been published on the causes and treatment of infertility in Estonia (for example Salumets et al. 2008; Haller-Kikkatalo and Sarapik 2009) within the past decades plus the topic has had media coverage, the average knowledge of the general population is still superficial, limited and simplified, as pointed out in the following response: 
I have often bumped into the opinion that when the first attempt of IVF [in vitro fertilisation] is made, it will be an immediate success and twins or triplets will be born. People also think that if someone gives a multiple birth, this is because of artificial fertilisation. People don't know who is a test tube baby and doubt if such a child can be its parents' child at all or will grow in the laboratory all the time. Also, many think that test tube babies are somehow strange or different. When people hear that someone has problems with fertility, good-hearted people who want help suggest, as a rule, folk medicine or alternative therapies. (F71, age group 25-30)

The media has promoted an opinion whereby infertility treatment is extremely simple (more on the interaction of simplified and sensationalised media representation, and societal values and narratives see Briggs and Hallin 2016). Advertisements of reproductive clinics usually show only happy families with children (cf. Throsby 2004: 3). The people who are not familiar with the topic may easily get the impression that every childless couple can conceive a child with the help of infertility treatment or by making adjustments in their lifestyle, and if they have not done so, it is their own choice. One respondent describes recommendations that are based on simplified understanding: "They accuse you of an unhealthy lifestyle, should you do anything qualifying as such, for example 'Just give up the beer you drink after sauna and you will immediately get pregnant"' (F17, age group 31-35).

Some respondents noted that according to common understanding in Estonia, the ideal family should consist of two parents and two children and people presume that everybody should strive towards the same ideal (cf. a similar observation about Australia by Moulet 2005: 5). As motherhood is romanticised and heroicised, childless women perceive an accusation that those who do not fulfil the motherhood function are unnatural, non-feminine, incomplete or even pathological (cf. ibid.: 8-9). My survey shows that women feel the prevalence of such attitudes clearly and often take them over themselves, striving towards the family norms imposed by society.

However, according to some respondents, society also has doubts about the value of children born from in vitro fertilisation (for example their intellectual abilities, vitality). Respondents repeatedly noted that when other children have behaviour or health problems, it is considered normal, but when similar problems occur in 'those' children, in vitro fertilisation is pointed out immediately as the cause. Among childless, but also other people, fatalistic attitudes were strongly represented - as causes of infertility the respondents mentioned karma, destiny, god or the course of nature that would be useless, inappropriate or impermissible to resist. One respondent said: "Sometimes indeed the thought enters my mind that maybe I'm paying off some karma debt from a previous life or paying for the sins of my ancestors" (F99, age group 36-40).

Due to the prevalence of ambivalent attitudes, many individuals with fertility problems have developed a taboo regarding childlessness and infertility treatment and simply avoid talking about the topic. On the other hand, they try to construct model explanations that help them find the least painful middle ground between societal role expectations, personal ideals and beliefs related to supernatural guilt and punishment. The next example, despite its light-hearted manner, reflects certain inner negotiations between the course of destiny and the fulfilment of individual dreams: 
I have been thinking that maybe my destiny just wanted that I would not pass on my genes. But as both my [in vitro fertilisation] attempts succeeded first time, I 'comforted' myself with the assertion that these attempts would not have succeeded so easily if destiny was against it :). (F1, age group above 40)

Several authors (see Moulet 2005: 11,31) have claimed that in contrast to the perception of motherhood as something 'compulsory', fatherhood is regarded as a more optional role by the society and men cope with childlessness less painfully. The situation does not look that unambiguous when reading the Estonian responses and some international studies have also shown that the psychological reaction of men who acknowledge they may be the cause of infertility can be more serious than in women because men perceive their condition as socially more stigmatising (Daniluk 1997; Malik and Coulson 2008: 18). On the other hand, the impact of infertility on men has not been investigated enough and within my survey just one tenth of the responses came from men. However, the responses either given by men, or describing their reactions, showed beyond doubt that infertility can be traumatising and cause deep masculinity crises, as described in the following response:

Childless couples who are not very young any more are regarded as weird. Usually people quickly jump to a conclusion there must be something wrong with the man, that he's 'shooting blanks'. This is a cruel attitude as men suffer a lot from their infertility. (F73, age group up to 25)

The gender aspect is also pointed out by Tine Tjørnhøj-Thomsen (2005: 78), who says that the feeling of not being 'real' - a real man, woman or family - was a prominent topic in the stories of the infertile men and women she interviewed. Some respondents said they went to see a clairvoyant or an alternative healer with their partner, or that both partners shared similar views regarding the causes of infertility, thus one could conclude that at least some beliefs described in this study also occur in men, although in a more concealed form than in women.

\section{CHILDLESSNESS AS CRISIS AND LIMINAL STATE}

It became clear from the survey that learning about one's infertility can have a similar effect to being diagnosed with a serious illness (such as cancer or AIDS; see for example Miles et al. 2008: 238), although infertility does not usually cause pain, physical constraints or reduction of life expectancy. However, the individuals concerned may perceive their situation as a matter of life and death psychologically, in the sense of their personal identity. Involuntary childlessness is seen as a deviation from the culturally and socially acceptable life cycle; it disrupts the future perspectives of the person, thereby causing - because of the incompatibility with the culturally pre-determined biographical narrative model - a "narrative loss" (cf. Tjørnhøj-Thomsen 2005: 76), or, in other words, an inability to construct a biographical narrative that would satisfy both the society and the person. The crisis is often expressed in micro-narratives, in just a word or phrase, that still carry cultural values and connotations related to vernacular beliefs, as with the following self-reflection: "The feeling is as if I was incomplete, 
broken, garbage" (KOM 110, perekool.ee). Behind such short statements we can often assume a years-long narrative of decoding and defining of the experience.

Thus, involuntary childlessness is often experienced as a crisis with long-lasting effects on those involved: for example one third of childless women develop serious symptoms of depression (Nelson et al. 2008). Allan (2009: 97) refers to infertility as a liminal experience and compares it to the three phases of the rite of passage described by Arnold van Gennep (2004 [1909]), where, in our case, the final phase can be either becoming a mother or adapting to the role of childless person. Allan (ibid.) points out that a number of liminal states or situations (for example the death of a family member) are historically legitimised and people going through those situations are offered help until the normal social order returns. Additionally, the society has accepted the increased level of sensitivity of such individuals and therefore also their propensity to magical behaviour (for example protective rituals related to funerals to avoid harmful supernatural contact) which may accompany such periods. Involuntary childlessness, on the other hand, is not seen by society as a liminal social experience. Yet, magical beliefs and rituals can be viewed as a reaction to the crisis, as a mechanism to protect one's identity: in such extraordinary situations people are more eager to use tools they would normally not consider. Therefore, introducing the concept of liminality (see more on it in Turner 1974) seems appropriate in this context. However, it should be stressed once again that the above-mentioned liminality discourse does not apply to women who have voluntarily chosen not to become mothers.

As stated before, only a few infertility studies (for example Bernstein et al. 1992) have mentioned beliefs and belief-driven behaviour. The following papers have made brief references to magical beliefs, but conclusions on their frequency of occurrence vary a great deal. Tjørnhøj-Thomsen (2005: 87-88) notes in her study: “The majority of the infertile couples in my study thus combined biomedical fertility treatments with alternative health care, sometimes they also took to prayer or magic in order to cope with the uncertainties of biomedicine and technology". Other authors say in their studies that among infertile couples in some Western research settings, more than $10 \%$ report having used alternative medicine including New Age healers, magical stones and crystals, religious amulets, and pilgrimages to places of worship (van Balen et al. 1995). Bernstein and his colleagues (1992: 336) also refer to the occurrence of magical thinking in infertility patients.

Howard Leventhal and his colleagues (1984) were amongst the first to list parameters that generally define how a person perceives his or her medical condition and handles it. They observed that individual beliefs are organised around five dimensions: the identity of the condition (driven by symptoms experienced); the timeline (long-term or short-term); the consequences (degree of severity); the causes attributed to the condition (external or internal); and the perceived control over the condition. People form their cognitive representations of their state and strategies of coping according to these elements. The responses to my survey indicated that with involuntary childlessness the duration, the alternating of hope and hopelessness as well as changes and modifications in related beliefs play an important role in the adjustment process. It can be concluded that the affected people seldom behave as passive victims; quite the contrary, they actively focus on finding solutions - magical approaches are one amongst many attempts to solve the problem. Thus, in the given context magical beliefs have a very 
pragmatic function. Although Bernstein and his colleagues (1992: 337, 339) claim that the magical beliefs of childless couples obstruct them from seeking rational methods, my material did not confirm the supposition whereby people forgo medical approaches because of their magical beliefs. Rather, it is valid to say that the longer the involuntary childlessness persists, the more likely the affected people are to try all possible methods, including the magical ones.

\section{THE TEMPORARY NATURE OF MAGICAL BELIEFS}

Little attention has been paid to the fixedness or changeability of magical beliefs related to childlessness and other health conditions. If at all, authors have stressed that the perceptions and beliefs related to illnesses are relatively stable (Rutter and Rutter 2007). On the one hand, the responses to my survey also implied that some explanation mechanisms (for example the concept of curses, supernatural punishment, destiny) and attempts to heal (traditional magical interventions) are similar to mechanisms found more than a hundred years ago (for more about these see for example Kõiva 2014; Hiiemäe 2017: 25, 35). However, regarding such beliefs among my respondents as a process, there is good reason to claim that in the individual course of events they are often temporary and subject to change and, as such, a healthy part of a psychological self defence strategy that helps the affected individuals overcome the emotional stress and uncertainty related to the experience of involuntary childlessness. In the following responses alternation of believing and non-believing and at times even their simultaneous occurrence can be clearly observed.

In difficult moments, of course you start thinking that a magic spell is cast on you, but rationally I don't believe it. (F5, age group 25-30)

There are many [rituals]. Such as wearing striped socks and red knickers during IVF procedures. By the way, it seems to have worked in my case, but still the pregnancies lasted only a very short time. Actually I don't believe it very much. Everything will be as destiny has foreseen it. (F44, age group 31-35)

Involving supernatural means for pragmatic reasons is not something specifically characteristic of involuntary childlessness, rather it can occur in many other complicated life situations, such as, for example, the parents of a mysteriously missing son explaining in a newspaper article:

You may think we are fools if you like, but when some pendulum magician says you should look here or there, then we indeed go and look. I have never believed such things, but these are our straws that we clutch at. (Eesti Ekspress 2016: 11)

Thus, the responses are in line with my preliminary argument that at times of personal and societal crisis people are more prone to supernatural explanations and magical solutions and irrespective of the person's education or intellectual level there is a tendency to hope for miracles. However, when the crisis is over, people can adjust their beliefs or return smoothly to the rational worldview, as shown in the following response: 
I had some early miscarriages and then I thought that they were caused by my partner strongly objecting to becoming a father. Later, when I started living with another partner who had nothing against becoming a father, we very quickly became parents :) Although, for the time being, I no longer believe that the will of another person can influence your fertility so decisively. (F102, age group above 40)

The authors who explain infertility through the theory of phases of grief (for example Daniluk 2001) give the impression that the process of explaining one's experience is one directional, and that once all phases are passed, acceptance of the situation will be reached, completing this definitive process. My survey responses, however, indicate that this process is not necessarily one directional, although in some cases people can indeed find a suitable explanation model and seek no further. However, with similar frequency, cases of repeated defining processes occur that can spiral back to the same beliefs or modify beliefs that no longer serve the purpose. At the same time there can be an alternation between believing or hoping, and non-believing. Changes in the broader belief background (for example the invasion of new beliefs through the mass media) and the on-going development of reproductive technology both play a role in the process. Several responses that gave retrospective glimpses of beliefs revealed the rethinking of beliefs and behaviour, for example:

With the consent of a well-known fertility doctor my husband went to Vigala-Sass [a well-known healer]. But sometimes things are such that magic spells and roots from miracle plants don't work and only conventional medicine can help. (F23, age group above 40)

In the following response, competing theories again occur simultaneously and the respondent concludes that karma debts do not exclude the possibility of getting help:

Karma or punishment... I have thought this about myself but I still think that [infertility] is like any other illness, like flu. When people get flu they don't think that it is punishment and they should stop taking medication and die from high fever, they still try to cure themselves. Thus, it's better not to make things more complicated. You have to believe and continue trying. (F44, age group 31-35)

Negotiating different beliefs, attempting to find a common ground and redefining convictions and understandings come to a stop with the birth of a baby, in other cases there is no clear-cut stop. Such openness seems to come hand in hand with the multiplication of choices characteristic to postmodernism and postsecularity (Moberg et al. 2012) and the increasing dynamism and flexibility of thinking in the light of today's technological development. A comparison with a more traditional village societ $y^{2}$ a hundred years ago shows that the supernatural explanations of that time were often more fixed and final (it may still be the case in deeply religious populations with more traditional lifestyles, for example see Roberts 2016: 215 about the role of God in the infertility treatment of women in Ecuador). In modern times the continual development of new medical technologies (for example the extending of the reproductive lifespan through artificial fertilisation) makes it difficult for individuals affected by infertility to stop their attempts to find a solution and just accept their childlessness as final, although, according to several studies, the definitive decision to end long-term attempts can bring a strong feeling of relief (cf. Moulet 2005: 29). At the same time, Moulet (ibid.: 119) describes how the 
women whom she interviewed continued hoping that they would get pregnant in some miraculous way even years afterwards, sometimes even after the menopause.

The most intense defining processes are related to vernacular beliefs on identity and the feeling of guilt. The fact that one has tried everything possible helps one fight the feeling of guilt and potential accusations from others.

Susan Folkman (1984) has referred to two types of mental coping: emotion-focused coping that regulates the emotions and reactions related to a situation, and problemfocused coping that aims to change a problematic situation. In the context of involuntary childlessness the former entails drawing subjective conclusions about the causes of childlessness, while the latter to particular magical interventions that aim to enable the affected people to become parents. The survey responses express a wide spectrum of beliefs covering both areas.

\section{SUPERNATURAL EXPLANATIONS OF CHILDLESSNESS}

A number of psychologists have pointed out that the reaction of individuals to uncontrollable events depends on the meaning they attribute to such events. For example Richard Lazarus (1973: 168) was one of the first authors to demonstrate that with stress reactions objective circumstances play a lesser role than the subjective evaluations by the experiencer. Subjective explanation found for illness offers affected individuals a certain feeling of control: unable to choose their experience, they can at least decide upon the meaning. The attributed meaning may, in turn, guide the choice of methods used to overcome the unwanted condition.

With unwanted childlessness the social dimension and individual attempts to make sense of the experience become intertwined. Folklorist Piret Paal (2010: 31) has pointed out in the context of cancer patients' individual narratives that their illness descriptions build a dialogue between the personal cancer experience and culturally accepted ideas and social practices. With childlessness it is more appropriate to talk about interaction between both - personal and cultural - dimensions. Socio-cultural explanation patterns are adapted to personal life. Supernatural explanations are encouraged by the media, oral communication and other channels used to overcome the social identity crisis. However, although individual beliefs are boosted by peer pressure, for instance constant questioning by others about why a couple does not have children and might it, perhaps, be their own fault, magical explanations are not meant to answer such questions or act as self-justification presented to others, they rather emerge to support the affected individuals themselves.

With infertility and other health conditions, people often first take the stance that the problem is temporary (cf. Leventhal et al. 1984). The longer the unwanted condition persists, the more likely it becomes that supernatural beliefs will be included in the line of possible explanations, especially when there are no scientific or logical reasons. Subsequently there are four possibilities: 1) the woman/couple becomes pregnant and puts the belief system that was built around childlessness aside as no longer necessary, 2) infertility persists and the woman/couple comes to terms with its permanent nature and find a belief that enables her/them to stick to her/their world outlook and identity, 3) infertility persists and the woman/couple find a rational explanation and 
reorientation, for example deciding that their bodies are not suitable for pregnancy for health reasons; they may go on to find their calling in career, travel or taking care of the children of other people, 4) no satisfactory explanations are found, which is the most difficult way of coping.

The survey responses contained numerous ideas on the supernatural causes of childlessness, attempts to object to the absoluteness of such ideas and self-justification. While cancer memorates often include accusations addressed to doctors (Paal 2010: 166), the doctors of reproductive medicine were only criticised in rare cases and people attempted to see their situation from a broader, metaphysical perspective. Many responses demonstrated that attributing childlessness to karma or destiny offered certain consolation. One respondent said that accepting the idea of predetermination helped her to find comfort in explanations like "Everything is good for something," or "This is how destiny wanted it to be" (F33, age group 36-40). Destiny and karma are often depicted as immutable forces, but with certain reservations, as becomes clear from the following disputation: "Generally speaking, destiny is predetermined and people can change only a little with their free will. But they still can, especially with positive thinking" (F29, age group 36-40). There were also several responses in which faith in destiny was combined with self-accusation, particularly with respondents who did not connect destiny with previous lives but with mistakes made in this life (for example with abortions or with having too many sexual partners). But even in those cases the respondents kindled hope in supreme intervention, or a miracle:

I have often thought that maybe I have not been determined to become a mother at all. I accuse my body - I was born as a woman but my body is unable to perform this one female function that women should be able to. I very often come to think that I have obviously deserved it in some way, karma or something. Of course, I have made many stupid things in life but I would still want to hope that I would not be punished that harshly. I have heard that it is possible to improve the situation with healing herbs and I have tried to do so. (F73, age group up to 25)

Response texts include a disproportionately high level of self-accusation for inappropriate lifestyle and sometimes rational-medical explanations are intertwined with the supernatural ones. For example, the next response text signals that the objective medical indicators of the husband were weak. However, the respondent still considers supernatural punishment to be the cause of the couple's failure to conceive:

Within two years I had several ectopic pregnancies and henceforward it was impossible for me to have children in a natural way. [...] During treatment it became clear that the sperm quality of my husband was also very poor. Now I think these ectopic pregnancies were a punishment for abortions. (F28, age group 36-40)

The perception of causal connection between childlessness and particular behaviour is rather characteristic. There are frequently expressed opinions that infertility is caused by sitting on a cold stone in childhood, by a large number of previous sexual partners, by smoking or by alcohol abuse as a teenager. It is very likely that the actual lifestyles of childless people vary a great deal more than those black-and-white presentations may suggest. 
Discussions over the predetermination of childlessness often get to the point of supernatural punishment, and in such cases the personified god is frequently included in the explanation. Barbara Eck Menning (1984: 20) points out that even the most enlightened and educated people she has counselled have expressed a mystical belief in their infertility being God's punishment, and this even in the absence of other religious convictions. To give a broader cultural background, it should be noted that in the Bible childlessness and getting over it are depicted as God's decision. The Bible says that when God wanted, even the hundred-year-old Jacob and his ninety-year-old wife Sarah became parents (Genesis 17:16-20). However, in some cases the modern use of the image of a personified God can be placed on the borderline between faith and metaphor, as in the following figurative description: "When our first child became 1.5 years old we tried to get pregnant again, but it would be too much to expect that God would send you a jackpot twice" (KOM 111, Perekool). However, in several folklore studies metaphorical expressions are interpreted as remnants of mythological thinking (for example Siikala 1992: 155) and when verbalising and interpreting an experience, people often grasp at the models latently present in the culture. In the following sample text psychological reasons are listed that support involving the concept of God's will in the explanation model:

When you have tried hard but can't get a child by whatever means, then automatically the thought enters your mind that it is about karma and apparently God didn't want [it to happen]. In the end there is no big difference if God wanted or not, you just feel better yourself when you have somehow explained these things to yourself and don't need to accuse yourself. (F25, age group 36-40)

Remarkably often (in more than $20 \%$ of the response texts) an evil curse was mentioned as a possible cause of infertility. In most cases the connection was made with a curse cast on a person in this lifetime; the viewpoint that a curse could last for several generations occurred only in some texts, for example in the following:

When clairvoyants talk about karma, they argue that one of your fore-mothers did not want children or cursed the children born to her. Most such beliefs are about the female lineage, because an infertile woman will leap more to the eye than an infertile man. (F50, age group above 40)

However, several responses indicated that the respondents had no clear definition of concepts like karma, curse, destiny, the course of nature, and used them interchangeably. The attempts to change destiny or karma can be expressed in active interventions or counteractions that aim to even out the errors of past or present lifetime. Such logic is illustrated in the following text:

I have had the feeling that when I do good, I will be rewarded. Say I give a donation to an orphanage - this way I somehow deserve more, that a child will be born to me. Or there are some spiritual rules in the world that keep record of such deeds. (F25, age group 35-40) 


\section{MAGIC INTERVENTIONS FOR CONCEPTION}

The survey demonstrated that only one in five respondents had neither used magical or ritual interventions nor heard of others using them. The respondents mentioned the use of healing herbs and certain food, the blocking of unfavourable influences (for example protective magic against bad people or energies), rituals for conception (including following certain taboos), metaphysical communication (for example seeking contact with the soul of the child), as well as approaches of a more psychological nature, such as positive affirmations, conscious letting go and creative visualisation. Many individuals had visited miracle healers or clairvoyants. It should be noted, however, that these methods are not exclusively characteristic to the Estonian context; many such methods have also been observed in other Western settings (for example, regarding Australia see Bernstein et al. 1992: 337). Several respondents presented a long list of magical approaches they had tried. Such descriptions indicate how hard the affected individuals are ready to try to overcome the crisis and reach the desired outcome. The following response offers a set of ritual approaches, where medical and psychological methods transmute step-bystep into magic:

Certain activities: before IVF breathing exercises, magic charms, massaging the uterus in a certain way. Avoiding certain foods that could prevent success (e.g. foods containing vinegar, acidic foods, dairy products, blue cheese, etc.). I have also given many different promises that I said I would fulfil should my IVF succeed. Also, I have considered various comforting things to do, should the attempt fail (e.g. me and my husband would go on an expensive trip or buy something costly). Sometimes I think maybe it is predetermined that these promises will not be fulfilled, and that this is the reason why the attempts fail. I have not worn talismans, but I have hidden juniper and rowan twigs in a small birch bark box and keep it buried in the north-east corner of my house. From time to time I cradle it (which is meant to symbolise a boy and a girl and their cradle). You have to keep it even for 100 days after the birth of your children, every day symbolises a healthy and strong living year for your child. (F71, age group 25-30)

Many responses revealed that conventional medical treatments, therapies with no medical status in Estonia (TCM, reflexology) as well as magical approaches were simultaneously used and certain magical rituals were even related to conventional medical procedures. For instance, there are suggestions to change clinic after repeated failures, although the reasons vary from purely medical (different doctors have different levels of experience and different methods) to more metaphysical ones, for instance the idea that the negative energy of previous failures can accumulate in the clinic and hinder success.

Food recommendations play an important role, including instructions that qualify as close to a magical approach. The popularity of such instructions is partly due to skewed claims in the articles published in media and then further amplified in interpersonal communication. There are, for example, disproportionately high numbers of references made in Internet forums and in survey responses on certain types of food that is supposed to be good for conception (for example eating the core of a pineapple, drinking an infusion of lady's mantle or a daily glass of red wine). These suggestions are often 
accompanied with ritual-like instructions on when, how much and in what way to eat. For instance it has been mentioned that a woman should eat $1 / 5$ of the core of a pineapple for 5-6 days following the IVF procedure, but definitely no longer. Suggestions are presented as absolute imperatives and do not specify whether following them would just help to get pregnant or if they work as a universal miracle remedy. For instance, one post from an Estonian Russian-speaking forum suggests that a couple who want to get pregnant should eat grapefruit daily because fertility depends on vitamin $\mathrm{C}$, which makes the sperm properly liquid (KOM 112, Eestimamki). The following sample text is characteristic to the dynamics of the spread of such suggestions:

Lady's mantle plant infusion (to prepare the mucous membrane of the uterus, I guess), pineapple, grapefruit juice, pomegranate - I don't remember exactly when one must consume what, but at times those foods were indeed in fashion. Somebody starts suggesting something because she has read about the good effect of it and the others will soon follow. (F55, age group 36-40)

Methods applied to directly influence the organism of a woman are combined with protective magic to protect the woman or, in a broader sense, the whole family against the effects that can impede conception. Protective magic combines beliefs from different time periods. People have the ancient fear of the evil eye and curses, but there are also more recent perils like energy vampires or harmful energies emanating from the ambience that are rather characteristic to modern vernacular beliefs. The following response text, for instance, lists specific protection instructions combining magical objects, rituals and spells:

I have been thinking that the ability of some evil person to send 'bad wishes', so to say, could influence your ability to get pregnant. Several people have said me what to do for protection, for example: light a white candle - the symbol of positive and pure thinking; watching the flame also has a calming effect that can relieve tension; when a bad person, say an energy vampire, is approaching you, think: "You will get no energy from me!", but you can also think: "Between me and you there is an invisible wall and you cannot cast a bad wish on me!" I have also been thinking: "All bad wishes that you cast on me will come back to you. But if you wish me well, it will come back to you double." (F91, age group 25-30)

It is characteristic of contemporary belief-induced behaviour that only some belief elements are applied, for instance a magical object is bought (for example a semi-precious stone, a talisman), because the buyer has heard that it helps her to get pregnant, but she does not know exactly how such objects should be used. In the following text a respondent describes her experience of prayer, saying that she did not know who she should address her prayer to:

I remember that at some point I was praying in my thoughts for a child to be born, and after that, for the health of that child. I don't know to whom I was addressing my prayers, but I'm sure the higher powers figured it out already themselves :). (F30, age group 36-40)

Another respondent does not specify whether her attempts were successful because of chance or because she wore a talisman. However, she makes a narrative connection to the talisman: 
Years ago my mother asked a Latvian astrologist to draw me a horoscope and it suggested I should wear a golden key to get a child. I must say that when I was wearing the key, the IVF attempts were always successful :) Was it just a lucky chance or something else - who knows :). (F42, age group 36-40)

The context of some responses, however, allows the assumption that there are also involuntary childless individuals who categorically exclude any magical intervention. The analysis of such responses is not the focus of this paper, but it should still be noted that not everybody perceives involuntary childlessness as a major crisis; some use rational means of coping, like adoption.

\section{THE MEDIA INFLUENCE}

The media plays a significant role in shaping the prevailing attitudes and certain magical beliefs related to childlessness. The authors of a survey that studied attitudes to involuntary childlessness in six European countries, the USA and Australia underline that the media likes to focus on ambiguous or extreme cases of in vitro fertilisation; only seldom does it attempt to present balanced information about infertility, therefore skewed or simplified presentations often reach the public (Adashi et al. 2000: 330). The media rarely tells positive stories of couples who are happy despite of their involuntary childlessness. Instead, success stories are published of childless couples who finally have a child, and even in those cases there is usually no mention of any magical beliefs or the doubts the couple had to face in the process. Talking about irrational ideas and experiences in public is held to be culturally unacceptable and so people who hold such beliefs can feel isolated. Several respondents admitted they do not have the courage to share their magical beliefs because they fear they will be misunderstood or condemned.

On the other hand, the people promoting themselves as alternative healers, shamans and miracle doctors increasingly often feature in media interviews; many highlight their ability to cure even the most serious conditions, such as cancer and infertility with just one or two sessions. Some healers even claim they know the exact number of children born with their help. A healer named Aavo is said to have brought people back from coma and helped couples to produce twenty children within one year (see Naisteleht 2011). Some media articles have juxtaposed medical infertility treatment and magical healing. In one article a healer named Volli describes his healing work:

I met people who had undergone two in vitro fertilisation procedures that failed completely. We had just one session and they asked when they could expect a baby. I usually say that in the first month nothing happens, but in the second or third month women get pregnant. This couple had their long-awaited surprise three months later. (Õhtuleht 2010)

The media's constant highlighting of information related to so-called miracle healers contributes to such help becoming psychologically more normalised and accepted. The media paradoxically gives voice to the miracle healers, while the voices of people who have doubts or are disappointed in their help are rarely made audible. Childless individuals share such experiences in anonymous Internet forums, if at all. In a number of Internet forum discussions healers' contact details are shared, mediated by people who 
have started believing in their abilities based on their media representation. Through the media performances of witches and healers, new magic methods and tools reach the public, as becomes obvious from the following response: "I know there are crystals and amulets that help against illnesses and can influence fertility. The witch Marilyn Kerro had a crystal on a TV show that, according to her, would help her have children in the future." (F51, age group up to 25) Semi-precious and magical stones are a novel feature in the Estonian vernacular health belief system. It is very likely that those beliefs have started accumulating in the last decade specifically because of media coverage. Crystals (rose quartz for example) were mentioned in more than $10 \%$ of the responses.

The next action narrative describes how a childless woman successfully followed advice presented in the media:

After a TV show where they talked about Kirna Manor (the alley of lovers, benches that help women get pregnant, etc.), a friend who very much wanted to get pregnant went there on a group tour. I was telling her rather jokingly that make sure to sit longer on the fertility bench; next month her pregnancy test was positive. (F16, age group above 40)

Clairvoyants and healers, however, lay the final responsibility on the childless couple, both in the media and in private sessions. For example, weekly Kroonika (2009) published an online interview with two clairvoyants who claimed that every single woman could get pregnant and have a child, should she only believe and want it strongly enough. A healer who positions himself as a modern shaman says that the problems of childlessness will only vanish once the childless person has given up his or her feisty attitude towards his or her parents (Antsov 2010). Thus, feelings of guilt are also reinforced in childless people in this discourse. Analysing societal attitudes towards childlessness, Karen Throsby (2004: 133-134) concludes that when a woman is unable to have a child, she will be accused of something negative, yet when she finally has a child, medicine or miracle doctors are praised.

In addition to media articles, respondents also refer to books written by healers, for example one of the most widely quoted authors was the healer Luule Viilma, for example in the next response:

I have often come across [magical explanations]. People think that [infertility] exists for karmic reasons, because of an evil curse or a self-curse, when somebody subconsciously doesn't want children or is spiritually not ready and doesn't actually want to conceive. Luule Viilma has also said that first you should come to terms with your own mind, find your own fears (like being subconsciously convinced that a child would be a burden to the mother). (F17, age group 31-35)

Talking of the causes and treatment of infertility in a broader sense, the media often gives biased information that is not directly magical but which would spread among the people on the level of belief. A newspaper headline, for instance, claims that excessive sleeping may complicate conception. However, in the conclusion of the same article it is said that this is not actually clear, because there are too many factors simultaneously in action which all affect conception (Postimees Naine 2015). Another newspaper article makes a reference to researches saying that healthy food could increase the fertility of men, yet consuming dairy and meat products in excessive quantities might reduce 
fertility (Postimees 2009), giving the misleading impression that just by changing one's diet one can cure infertility, although the article gave no information about the potentially harmful quantities of meat and dairy products. Reappearing in Internet forums, newspaper recommendations have often morphed into imperatives (for example "If you want to get pregnant, don't eat red meat"). Thus, dealing with topics like healthy diet, the causes of infertility and methods of treatment, the media has a considerable affect on the development of vernacular beliefs and magical interventions.

\section{THE UNBORN CHILD AS AN INDIVIDUAL: GRIEF AND PERSONAL POWER NARRATIVES}

Survey responses and respective forum posts indicate that women/couples who undergo fertility treatment, or just try to conceive a child, can perceive a normal monthly cycle (the start of menstruation) as yet another link in the endless cycle of failures. They feel that they grieve for a real child when the truth is they have only lost the possibility to conceive a child. However, the culturally acceptable ways of grieving cannot be applied here, as the individual whose loss they grieve did not exist in the first place.

This is probably one of the reasons why narratives depicting the unconceived child in a personified way emerge. Several respondent women described their supernatural contact with their unconceived child in dreams, visions and imagination. Such communication gives their experience a certain new representativeness and focus, thereby bringing a cognitive change: there is now a child who communicates with a mother. Even fertilised egg cells, i.e. frozen embryos, are often equated to a child (cf. about this proposition Raffler-Engel 1998-1999: 228). Supernatural contacts and related personal beliefs give the experiencer certain independence: internalisation or direct contact with the child becomes the woman's personal reality independent of destiny, doctors, healers or anything else. Thus, in this context, such personifying narratives can be called "not only structures of meaning, but also structures of power" (Bruner and Turner 1986: 144). Edward Bruner and Victor Turner use this expression to characterise the narrative presentation of human experience in a broader sense, while I use it here to refer to the functioning of such narratives as a helping tool for regaining a personal feeling of control. One would think that when no pregnancy follows or it spontaneously terminates in an early phase, such personified imagination would rather increase the feeling of loss. However, in such cases the same child can take over the role of a comforter, as described in the following text:

Once I barely had the chance to confirm my pregnancy with a test before I had a spontaneous pregnancy loss. I felt terribly sad and depressed. Then I got a poem from my child in a dream. I didn't see the child, but the poem just came to my mind. It was a beautiful poem where my child apologised for not being able to stay and thanked me and asked me to remain peaceful. I felt better then. (F104, age group above 40)

In the majority of cases the child is depicted as being able to talk (the child often passes messages), the outer appearance can be that of an infant or a toddler, or an angel. Descriptions of the children 'seen' by clairvoyants as dwelling in the spiritual world 
probably contribute to the personifying beliefs of the childless people. The next sample text offers a narrative that was formulated following an unsuccessful visit to a healer:

I have been thinking about what I've done wrong in life that I should be punished the way I am. Then I realised infertility is not a punishment, but a lesson I have to learn in this life. In my mind, this is the reason for my infertility. We visited a miracle doctor to learn more about the reasons for our infertility and when - if at all - we would become parents. This was a year ago. The doctor unblocked my chakras and said that within a year I would be a mother. Obviously this has not happened... The miracle healer 'saw' that there were three children about to enter our lives, two of them sons. According to him, the reason for my infertility was a stressed uterus and the strenuous deliveries of my mother, which had accumulated in me via my soul chakra, giving me the signal not to experience the same. (F21, age group 25-30)

The healers have also contributed to the spreading of a popular understanding whereby to get pregnant, the parents must first invite their unconceived children to join them, as described in the following response: "I recommend that childless women should talk to the soul of the child, praising it and convincing it of the great time they would have together" (F50, age group above 40). Such descriptions often combine psychological autosuggestion with spiritual concepts of the soul. The next level up in belief related to the soul of the child is seeing the child as the one who makes the decision. This accords with the belief that children choose their parents and the time they want to be born. The following text, for example, highlights how parental intervention is useless as the child must be able to choose when it wants to be born:

I have heard that the woman may have certain blockages that don't let her get pregnant, like the wrong time, impatience or interfering using different methods to get pregnant. It is believed that a woman should let her body and thoughts be free and give the child a choice as to when it wants to come, this way the woman is more likely to get pregnant. (F15, age group 25-30)

However, there was another category of belief that said that the free will of a child can also be limited by external circumstances. The following longer response is illustrative, describing the different stages of mediating beliefs and pointing out how somebody with paranormal skills can assume the role of authority, 'seeing' or sensing the causes of childlessness:

Some time ago I visited a masseuse who also practices alternative therapies and 'knows' various things about people. Halfway through the session, she suddenly told me I had great tension in the pelvic area, that all my sadness, negative energy, fears and similar were accumulating there (I never told her we were trying to get pregnant). She added that this was the reason I have been unable to get pregnant. Let me underline again that I had not told her about us trying to get pregnant, her words came completely out of the blue. But it made me think whether that might indeed be the case. Another thing: just yesterday I happened to meet a person with supernatural powers - the power to see your aura, unblock your energy channels, chakras, etc. Anyway, we met up and had coffee and suddenly she told me that the 
soul of a baby wants to come to me but cannot, because I have an energy blockage in the pelvic area (I don't remember her exact words or what was the name of the energy blockage, I think it was a sexual channel or something) and unless I released this blockage, the baby was unable to come to me. My mouth fell open and I had shivers all over my body... (KOM 109, Perekool)

It must be noted, however, that in older (i.e. pre-20th century) Estonian folklore the agency of unconceived children was depicted only minimally. When people looked for the causes of infertility as well as magical interventions both took place on the level of the adult world. Thus, narratives depicting unconceived children in a personified manner and as active communicators - agents - can refer to shifts in the perception of the role of children in society in general.

\section{PARALLELS BETWEEN MODERN AND TRADITIONAL BELIEF SYSTEMS}

The aim of this study is to cast light at modern vernacular beliefs on infertility in Estonia. However, in order to place these beliefs into a wider historical context, the following subsection was written to give an overview of the beliefs on infertility in the collections of the Estonian Folklore Archives reflecting the tradition of the 19th and early 20th centuries.

Societal attitudes towards childlessness have probably been non-accepting and condemning throughout history (except religiously grounded childlessness, such as with monks, nuns and some priests); childlessness has been considered a deviation from the norm. The female monsters of Ancient Greek mythology (for example the moirai, gorgones) where characterised by their childlessness and destructiveness. According to historian Linda McGuire (2010: 135) these images were later reflected in the European woman-as-witch stereotypes. In the Late Medieval period, when witch hunting was spreading in Europe, one of the main evils that witches were accused of was making women infertile and men impotent. However, this was not the first instance of associating infertility with witchcraft, which came in Antiquity with the sexual impotence of men being explained by many contemporary authors as having supernatural causes such as curses or witchcraft (cf. Ruff 2003: 217). Cultural historian Angus McLaren (1985: 31; see also chapter 2) notes in his study on the reproductive behaviour of women in 17th- to 19th-century England that "childlessness was one of the most severe maladies of women and people used potions and charms to prevent it".

A hundred years ago in Europe it was common to think the evil eye, a curse or some other witchcraft had caused infertility. Looking at the modern belief system, the same beliefs were repeatedly mentioned in the responses. Similarly to older texts, evil interference was held possible, as becomes obvious from the following response: "The existence of black magic is beyond doubt. I have no personal experiences but I don't exclude there being someone wishing other people bad luck." (F93, age group 36-40)

Seeing infertility as an unwanted and condemnable condition is also reflected in several traditional internationally known fairy tales in which the blame is more often laid - again - on women, emphasising, for example, that it was the queen who was unable to give the king an heir. Such fairy tales also make clear that infertility was a 
problem for all social classes alike. There are plenty of fairy tales in the international tradition that have also spread to Estonia in which (an old) couple wants a child, be it as small as a thumb, and finally has the child, who then later becomes a hero (for example Tom Thumb in English folklore, see more in Green 2007). Fairy tale type ATU 441 tells the story of a couple unable to conceive because of a curse. The woman finally gives birth to a hedgehog who, after winning the heart of a princess, turns into a wonderful young man. Thus, yearning for a child, and supernatural solution phantasies, are well represented in the older fairy tale tradition.

As the status of being infertile was openly dreaded, it was only natural that people tried to prevent it with magic. Fertility rituals were part of traditional wedding ceremonies; several manuscript texts say that the bed of the newly-weds must be made wet in order to avoid a childless marriage. While in the modern belief system verbal charms have a rather modest role, they are mentioned more often in the older tradition. For example, a book on Estonian customs in the 17th-19th centuries says that newly-wed women used to address the new moon, saying: "Let my womb swell as you will swell" (Boecler and Kreutzwald 1854: 25). Binding ribbons on a stork's nest to guarantee the couple plenty of children is still very much part of the wedding ceremony. As most families today do not wish to have more than two children, the implicit purpose of the ritual is not to have many children but rather to avoid infertility.

Medicinal herbs, too, have always had an important role in curing infertility, and their use is interesting because it often blurs the border between medical and magical function. For example, in Estonian folklore the rowan tree, which has a broad role as a magical plant is mentioned in a number of older and modern texts. In the next manuscript text, the use of a rowan tree is combined with ritual whisking:

This was what my father, born in 1830, told me when I was a grown man: When a woman is unable to get pregnant, you must make a whisk from rowan twigs and bring it secretly to the sauna. There you must whisk her between the shoulder blades but in a way she would not see that you are holding a rowan whisk. See, soon there is hope that she will become a mother! (E 52649 (2) < Paistu, 1938)

Many objects with a broader role as magical tools in the old Estonian tradition (for example a stick that had been used to kill a snake, an oblation, mercury) were also believed to cure infertility, although today these traditional objects are generally replaced with new ones (for example manufactured talismans, crystals). Many old and new rituals are based on analogy and contact magic. Old texts repeat that pressing a childless woman with a bottle cap or a cask bung or tucking a needle in her clothes will help against infertility. In addition it is claimed that slapping a childless woman with a garment (especially an apron) belonging to a pregnant woman will help her conceive. On the other hand, a fertilising effect was also expected from the symbols of potent male energy, such as slapping a childless woman with an oxen whip or with men's trousers. A similar effect was expected from bringing a bear or a hedgehog into the bed of a childless married couple. As today, there are numerous references to visits to a village healer in the archived folklore texts from the 19th and beginning of the 20th centuries. Thus, it can be concluded that many principles of magical intervention have remained largely the same, although their specific application - partly due to the influence of the media - has changed. 
It must also be noted that there are many pre-20th century folklore texts on inducing an abortion or avoiding pregnancy, but these should not be regarded as proof of many women not wanting children. The need to limit the number of offspring arose when there were already plenty of children in the family and the family could not afford to feed any more.

\section{CONCLUSION}

I have attempted to describe how models of explanation and reaction built of elements of belief can function as means of psychological self-defence. The experience of every childless person is unique; however, in the responses to the survey, certain time and culture related metaphors, explanations and intervention methods could be observed and the magical dimension they possess has an important role. Although outsiders and often even the people themselves might consider such beliefs and explanations a sign of inadequacy, they should still be regarded as a healthy attempt to define one's situation and actively seek solutions. Such beliefs have the potential to become counterproductive only when they start inducing irrational fears or affect rational life choices (for example, convincing oneself that infertility is the result of a curse and seeking help is therefore pointless, or not using the possibilities of conventional medicine because a miracle healer said so). Although such cases cannot be ruled out, my survey did not find any. Rather, it showed that those seeing their childlessness as a problem are willing to try all possible solutions available, with magical intervention being just one of them.

Contemporary material shows unprecedented pluralism, combining elements of the older (19th and the early 20th century) tradition, the esoteric philosophy and New Age spirituality and that of the canonical religions (Christianity, Buddhism) with an obvious influence from the media. Individual beliefs trigger changes in diet and lifestyle hoping that this will help the woman to conceive or giving the couple confidence knowing they have done everything humanly possible. Seeking help from practitioners of alternative medicine (miracle healers, clairvoyants) was repeatedly mentioned. Although childlessness was described as a difficult experience, the attitude towards help was largely optimistic.

(Quasi-)magical beliefs and perceived supernatural contact with the unconceived child help maintain a healthy self-image and transcend the role of helpless sufferer, as the self-analysis given in the following response confirms: "I guess these tricks all help at times of hesitation to maintain mental balance. Believing in something is grasping at straws and that cannot do any harm." (F33, age group 36-40) At the same time these coping methods are often temporary and change as necessary.

\section{NOTES}

1 According to general statistics, some supernatural and magical beliefs are rather widespread in Estonia: a 2015 poll found that $90 \%$ of respondents believe in some sort of karma (41\% totally agreed, $49 \%$ rather agreed), $62 \%$ thought that some people can magically cure illnesses. $54 \%$ of respondents agreed that angels protect and help people, and $54 \%$ believed that the constellation of the stars or planets at the moment of birth has an effect on one's character or fate. Every fourth 
respondent said she or he had a talisman or other object of magical protection (Saar Poll 2015). A 2010 poll found that $38 \%$ of respondents believed that it is possible to influence fate and other people with the help of magic (Saar Poll 2010; for an overview of contemporary religious beliefs in Estonia see Uibu 2016). Thus, personal explanation models and help-seeking strategies against involuntarily childlessness could be built on this foundation of belief.

2 Here and below I draw comparisions with the manuscript folklore materials stored at the Estonian Folklore Archives that have been collected mainly in the second half of the 19th and beginning of the 20th centuries.

\section{SOURCES}

Author's survey data from the period 2015-2016, preserved in the Archive of the Department of Folkloristics, Estonian Literary Museum (EFITA)

E - the manuscript folklore collection of M. J. Eisen (from the period of 1880-1934) in the Estonian Folklore Archives

\section{REFERENCES}

Adashi, E. Y.; J. Cohen, L. Hamberger, H. W. Jones Jr, D. M. de Kretser, B. Lunenfeld, Z. Rosenwaks and A. van Steirteghem. 2000. Public Perception on Infertility and Its Treatment: An International Survey. - Human Reproduction 15 (2): 330-334. DOI: https://doi.org/10.1093/hum$\mathrm{rep} / 15.2 .330$.

Allan, Helen Therese. 2009. Managing Intimacy and Emotions in Advanced Fertility Care: The Future of Nursing and Midwifery Roles. London: M\&K Publishing.

Antsov, Aive. 2010. Šamaan Tõnu Talimaa puhastab hinge Põhjala spiraalis. - Naised. https:// www.arengutee.com/totildenu-talimaa.html (accessed December 27, 2017).

ATU = Uther, Hans-Jörg. 2004. The Types of International Folktales: A Classification and Bibliography. Folklore Fellows' Communications 284-286. Helsinki: Suomalainen Tiedeakatemia, Academia Scientiarum Fennica. http://www.mftd.org/index.php?action=atu (accessed December 27, 2017).

van Balen, Frank; Jacqueline Verdurmen and Evert Ketting. 1995. Caring about Infertility: Main Results of the National Survey about Behavior Regarding Infertility. Delft: Eburon.

Bernstein, Joel; Martin Brill, Steven Levin and Machelle Seibel. 1992. Coping with Infertility: A New Nursing Perspective. - NAACOG's Clinical Issues in Perinatal and Women's Health 3 (2): 335-341.

Bruner, Edward M. and Victor Witter Turner. 1986. The Anthropology of Experience. Illinois, IL: University of Illinois Press.

Boecler, Johann Wolfgang and Friedrich Reinhold Kreutzwald. 1854. Der Ehsten abergläubische Gebräuche, Weisen und Gewohnheiten, mit auf die Gegenwart bezüglichen Anmerkungen beleuchtet von F. R. Kreutzwald. Petersburg.

Briggs, Charles. 2012. Toward a New Folkloristics of Health. - Journal of Folklore Research 49 (3): 319-345. DOI: https://doi.org/10.2979/jfolkrese.49.3.319.

Briggs, Charles and Daniel C. Hallin. 2016. Making Health Public: How News Coverage Is Remaking Media, Medicine, and Contemporary Life. New York, NY: Routledge.

Briggs, Charles and Clara Briggs-Mantini. 2016. Tell Me why My Children Died: Rabies, Indigenous Knowledge, and Communicative Justice. Durham; London: Duke University Press. DOI: https:// doi.org/10.1215/9780822374398. 
Brückner, Wolfgang. 1970. Magie. - Brockhaus-Enzyklopädie 11. Wiesbaden: F. A. Brockhaus.

Daniluk, Judith. 1997. Gender and Infertility. - Infertility: Psychological Issues and Counseling Strategies, edited by Sandra R. Leiblum. New York, NY: John Wiley \& Sons, 103-125.

Daniluk, Judith. 2001. Reconstructing Their Lives: A Longitudinal, Qualitative Analysis of the Transition to Biological Childlessness for Infertile Couples. - Journal of Counseling and Development 79 (4): 439-449. DOI: https://doi.org/10.1002/j.1556-6676.2001.tb01991.x.

Eesti Ekspress 2016 = Markkuse haihtumine. - Eesti Ekspress, January 6, 2016: 11.

Eestimamki = www.eestimamki.ee (accessed December 27, 2017).

Folkman, Susan. 1984. Personal Control and Stress and Coping Processes: A Theoretical Analysis. - Journal of Personality and Social Psychology 46: 839-852. DOI: https://doi.org/10.1037/00223514.46.4.839.

Franklin, Sarah. 1999. What We Know and What We Don't about Cloning and Society. - New Genetics and Society 18 (I): 111-120. DOI: https://doi.org/10.1080/14636779908656893.

Franklin, Sarah. 2006a. Embryonic Economies: The Double Reproductive Value of Stem Cells Biosocieties 1 (1): 71-90.

Franklin, Sarah. 2006b. Origin Stories Revisited: IVF as an Anthropological Project. - Culture, Medicine and Psychiatry 30: 547-555. DOI: https://doi.org/10.1007/s11013-006-9036-9.

Franklin, Sarah. 2013. In Vitro Anthropos: New Conception Models for a Recursive Anthropology? - Cambridge Anthropology 31 (1): 3-32. DOI: https://doi.org/10.3167/ca.2013.310102.

von Garmissen, Alexandra. 2009. Sinnstiftende Faktoren, religiöse Werthaltungen und Krankheitsbewältigung bei Frauen mit Brustkrebs. - Historical Social Research 34 (4): 204-216.

van Gennep, Arnold. 2004 [1909]. The Rites of Passage. London: Routledge.

Green, Thomas. 2007. Tom Thumb and Jack the Giant-Killer: Two Arthurian Fairy Tales? - Folklore 118 (2): 123-140. DOI: https://doi.org/10.1080/00155870701337296.

Greil, Arthur L. 1997. Infertility and Psychological Distress: A Critical Review of the Literature. - Social Science and Medicine 45 (11): 1679-1704. DOI: https://doi.org/10.1016/S02779536(97)00102-0.

Haller-Kikkatalo, Kadri and Aili Sarapik. 2009. Autoimmuunsus ja naise viljatus I. Soodumus autoimmuunsete reaktsioonide tekkeks. - Eesti Arst 88 (1): 14-19.

Hiiemäe, Reet. 2017. Folkloor kui mentaalse enesekaitse vahend: usundilise pärimuse pragmaatikast. Dissertationes Folkloristicae Universitatis Tartuensis 25. Tartu: University of Tartu Press.

Knecht, Michi. 2010. Ethnographische und historische Zugänge zu Samenbanken und Samenspendern. Eine Einleitung. - Samenbanken - Samenspender. Ethnographische und historische Perspektiven auf Männlichkeiten in der Reproduktionsmedizin. Berliner Blätter. Ethnographische und ethnologische Beiträge. Sonderheft 51: 6-28.

Knecht, Michi; Maren Klotz, Nurhak Polat and Stefan Beck. 2011. Erweiterte Fallstudien zu Verwandtschaft und Reproduktionstechnologien. Potenziale einer Ethnographie von Normalisierungsprozessen. - Zeitschrift für Volkskunde 107 (1): 21-47.

Kroonika 2009 = Online-intervjuu: Küsimustele vastasid selgeltnägijad Sergei ja Amita. - Kroonika, November 18, 2009. http://kroonika.ohtuleht.ee/616333/online-intervjuu-kusimustele-vastasid-selgeltnagijad-sergei-ja-amita (accessed December 27, 2017).

Kõiva, Mare. 2014. The Doctor Sent Me to the Folk Healer. - Through the Ages. Time, Space and Eternity. Sator 13, edited by Liisa Vesik. Tartu: ELM Scholarly Press, 143-158.

Lazarus, Richard S. 1973. The Self-Regulation of Emotion. - Philosophical Studies 22: 168-180. DOI: https://doi.org/10.5840/philstudies19732223.

Leventhal, Howard; David Nerenz and D. J. Steele. 1984. Illness Representations and Coping with Health Threats. - Handbook of Psychology and Health 4. Social Psychological Aspects of Health, edited by Andrew Baum, Shelley E. Taylor and Jerome E. Singer. Hillsdale, MI: Lawrence Erlbaum Associates, 219-252. 
Lloreda-Garcia, Jose María. 2017. Religion, Spirituality and Folk Medicine/Superstition in a Neonatal Unit. - Journal of Religion and Health 51 (6): 2276-2284. DOI: https://doi.org/10.1007/ s10943-017-0408-y.

Malik, Sumaira H. and Neil Coulson. 2008. The Male Experience of Infertility: A Thematic Analysis of an Online Infertility Support Group Bulletin Board. - Journal of Reproductive and Infant Psychology 26: 18-30. DOI: https://doi.org/10.1080/02646830701759777.

McGuire, Linda. 2010. From Greek Myth to Medieval Witches: Infertile Women as Monstrous and Evil. - Our Monstrous (S)kin: Blurring the Boundaries Between Monsters and Humanity, edited by Sorcha Ní Fhlainn. Freeland: Inter-Disciplinary Press, 135-152.

McLaren, Angus. 1985. Reproductive Rituals: The Perception of Fertility in England from the Sixteenth Century to the Nineteenth Century. New York, NY: Menthuen.

Menning, Barbara Eck. 1984. The Psychology of Infertility. - Infertility: Diagnosis and Management, edited by James Aiman. New York, NY: Springer, 17-29.

Miles, Laura M.; Merle Keitel, Margo Jackson, Abigail Harris and Fred Licciardi. 2008. Predictors of Distress in Women Being Treated for Infertility. - Journal of Reproductive and Infant Psychology 27 (3): 238-257. DOI: https://doi.org/10.1080/02646830802350880.

Moulet, Christine. 2005. Neither 'Less' nor 'Free': A Long-Term View of Couples' Experiences and Construction of Involuntary Childlessness. Doctoral dissertation. Victoria: Australian Catholic University, School of Social Work.

Moberg, Marcus; Kennet Granholm and Peter Nynäs. 2012. Trajectories of Post-Secular Complexity: An Introduction. - Post-Secular Society, edited by Peter Nynäs, Mika Lassander and Terhi Utriainen. New Brunswick, NJ: Transaction Publishers, 1-25.

Naisteleht 2011 = Aavo Ütsi kätes on imeline vägi. - Naisteleht. http://www.naisteleht.ee/content/ aavo-utsi-kates-imeline-vagi (accessed December 27, 2017).

Nelson Christian J.; Alan W. Shindel, Cathy K. Naughton, Michael Ohebshalom and John P. Mulhall. 2008. Prevalence and Predictors of Sexual Problems, Relationship Stress, and Depression in Female Partners of Infertile Couples. - The Journal of Sexual Medicine 8: 1907-1914. DOI: https://doi.org/10.1111/j.1743-6109.2008.00880.x.

Paal, Piret. 2010. Written Cancer Narratives. An Ethnomedical Study of Cancer Patients' Thoughts, Emotions and Experiences. Sator 10, edited by Mare Kõiva. Tartu, Helsinki: ELM Scholarly Press.

Perekool $=$ www. perekool.ee (accessed December 27, 2017).

Petzoldt, Leander. 2011. Magie. Weltbild, Praktiken, Rituale. München: C. H. Beck.

Postimees 2009 = Tervislik toit võib meeste viljakust suurendada. - Postimees terviselisa, June 10, 2009. https://tervis.postimees.ee/130058/tervislik-toit-voib-meeste-viljakust-suurendada (accessed December 27, 2017).

Postimees Naine 2015 = Kuus moodust, kuidas riskid liiga kaua magades oma tervisega. - Postimees Naine, February 17, 2015. https://sobranna.postimees.ee/3094981/kuus-moodust-kuidasriskid-liiga-kaua-magades-oma-tervisega (accessed December 27, 2017).

Raffler-Engel, Walpurga. 1998-1999. The Perception of the Unborn in the Diverse Sub-Cultures of the United States of America. - Intercultural Communication Studies 8 (2): 227-240. http://web. uri.edu/iaics/files/15-Walburga-von-Raffler-Engel.pdf. (accesssed December 27, 2017).

Rapp, Rayna. 2000. Testing Women, Testing the Fetus: The Social Impact of Amniocentesis in America. New York, NY: Routledge.

Roberts, Elizabeth. 2012. God's Laboratory Assisted Reproduction in the Andes. Berkeley, CA; Los Angeles, CA: University of California Press. DOI: https://doi.org/10.1080/01459740.2015.111 8100.

Roberts, Elizabeth. 2016. Gods, Germs, and Petri Dishes: Toward a Nonsecular Medical Anthropology. - Medical Anthropology 35 (3): 209-219.

Ruff, Margarethe. 2003. Zauberpraktiken als Lebenshilfe: Magie im Alltag vom Mittelalter bis heute. Frankfurt: Campus Verlag. 
Rutter Claire L. and Derek R. Rutter. 2007. Longitudinal Analysis of the Illness Representation Model in Patients with Irritable Bowel Syndrome (IBS). - Journal of Health Psychology 12: 141148. DOI: https://doi.org/10.1177/1359105307071748.

Saar Poll $2010=$ Public opinion poll "Elust, usust ja usuelust 2010", compiled by the public opinion research company Saar Poll. http://www.saarpoll.ee/UserFiles/File/Kiriku_uuring SLAIDID\%281\%29.pdf (accessed December 27, 2017).

Saar Poll 2015 = Public opinion poll "Elust, usust ja usuelust 2015", compiled by the public opinion research company Saar Poll. http://www.saarpoll.ee/UserFiles/File/Elus, \%20usust\%20 ja\%20usuelust_2015_ESITLUS_FINAL.pdf (accessed December 27, 2017).

Salumets, Andres; Ave Kris Lend, Maire Peters and Merli Saare. 2008. Mehe geneetiline viljatus. - Eesti Arst 87 (9): 628-634.

Siikala, Anna-Leena. 1992. Myyttiset metaforat ja shamanistinen tieto. - Metafora. Ikkuna kieleen, mieleen ja kulttuuriin, edited by Lauri Harvilahti, Jyrki Kalliokoski, Urpo Nikanne and Tiina Onikki. Helsinki: Suomalaisen Kirjallisuuden Seura, 155-183.

Tjørnhøj-Thomsen, Tine. 2005. Close Encounters with Infertility and the Procreative Technology. - Managing Uncertainty: Ethnographic Studies of Illness, Risk and the Struggle for Control, edited by Vibeke Steffen, Richard Jenkins and Hanne Jessen. Copenhagen: Museum Tusculanum Press; University of Copenhagen, 71-91.

Tjørnhøj-Thomsen, Tine and Helle Ploug Hansen. 2015. Managing Uncertanties, Gaining Control: The Magic of Foods and Words. - Between Magic and Rationality: On the Limits of Reason in the Modern World, edited by Vibeke Steffen, Steffen Jöncke and Kirsten-Maria Raahauge. Chicago, IL: The University of Chicago Press, 93-120.

Thompson, Charis. 2005. Making Parents: The Ontological Choreography of Reproductive Technologies. Massachusetts, MA: MIT Press.

Throsby, Karen. 2004. When IVF Fails: Feminism, Infertility and the Negotiation of Normality. Basingstoke: Palgrave Macmillan. DOI: https://doi.org/10.1057/9780230505704.

Turner, Victor. 1974. Liminal to Liminoid in Play, Flow, and Ritual: An Essay in Comparative Symbology. Houston, TX: Rice University Studies.

Uibu, Marko. 2016. Re-Emerging Religiosity: The Mainstreaming of the New Spirituality in Estonia. - Journal of Baltic Studies 47 (2), 257-274. DOI: https://doi.org/10.1080/01629778.2015.111 3432.

Õhtuleht 2010 = Tervendaja Volli aitab lapse saada ka lootuse kaotanuil. - Õhtuleht, July 22, 2010. http://m.ohtuleht.ee/648721/tervendaja-volli-aitab-lapse-saada-ka-lootuse-kaotanul (accessed December 27, 2017). 